\title{
Botanical Composition and Diet Quality of Cattle Under a Short Duration Grazing System
}

\author{
DONALD R. KIRBY AND MARK PARMAN
}

\begin{abstract}
A study was conducted in 1981 and 1982 at the Dickinson Experiment Station Ranch Headquarters in the mixed grass prairie of western North Dakota to determine seasonal and daily cattle diets under a short duration grazing system. Significant seasonal decreases in crude protein (CP) and in vitro digestible organic matter (IVDOM) were determined both years of the study. Dietary CP did not meet lactating and/or dry, pregnant cow requirements throughout the grazing season either year. In 1981, no seasonal difference in dietary $C P$ and IVDOM was determined between the initiation and termination of grazing on individual paddocks. Only one significant difference occurred in 1982 when dietary CP decreased significantly between the first and last day of grazing individual paddocks in fall. Grass dominated cattle diets both years of the study. The major grasses selected were western wheatgrass (Agropyron smithii), needle-and-thread (Stipa comata), and blue grama (Bouteloua gracilis). Cattle showed no consistent seasonal trend in grass or browse selection, while forbs decreased in diets as the grazing season advanced. Selection of forage species and plant classes by cattle while they occupied a paddock varied little during seasonal collection periods throughout the study.
\end{abstract}

Specialized grazing systems have not consistently been successful in meeting the nutrient intake requirements of grazing livestock (Lewis 1969, Launchbaugh et al. 1978). Short duration grazing systems (SDG), have been suggested as being able to increase carrying capacity while maintaining or improving individual livestock performance (Savory 1978). It has been suggested that SDG will enhance the dietary quality of grazing livestock by decreasing the maturity of available forage while consistently providing an adequate quantity of forage (Kothmann 1980, Heitschmidt et al. 1982a). However, little information is available to substantiate the enhancement of livestock diets or performance through the use of SDG (Heitschmidt et al. 1982b). An understanding of the effects of SDG on seasonal diets and diets selected within the occupation of individual paddocks is essential prior to applying this intensive grazing method.

The objectives of this study were to examine the botanical com-

\footnotetext{
Authors are assistant professor and research assistant, Animal and Range Sciences Department, North Dakota State University, Fargo 58105.

The authors gratefully acknowledge Mr. Tom Conlon, Superintendent, Dickinson Experiment Station, for his assistance in this study.

This article is published with the approval of the Director North Dakota Agricultural Experiment Station as Journal Article 1440.

Manuscript accepted 19 March 1986.
}

position and evaluate the nutritive content of cattle diets seasonally and within the occupation period of paddocks under an SDG system in the mixed grass prairie of western North Dakota.

\section{Materials and Methods}

The study was conducted during the 1981 and 1982 grazing seasons on the Dickinson Experiment Station Ranch Headquarters (T. 143 N., R. 96 W.), located approximately $35 \mathrm{~km}$ northwest of Dickinson, North Dakota. Annual average precipitation is 39 $\mathrm{cm}$ with $80 \%$ received during the growing season, May to September. In 1981 and 1982,20 and $66 \mathrm{~cm}$ of precipitation were received, respectively. Average daily temperature is $4^{\circ} \mathrm{C}$, with a monthly high of $27^{\circ} \mathrm{C}$ in July and low of $-13^{\circ} \mathrm{C}$ in January. Average length of the growing season is 120 days (USDA 1982). Vegetation is typical mixed grass prairie of the Northern Great Plains as described by Whitman and Wali (1975).

The SDG system was implemented by subdividing 130 ha into 8 equal sized paddocks radiating from a central watering facility. Paddocks were maintained on a 5:35 day graze: rest sequence and grazed with 35 cow-calf pairs each year. Grazing seasons were 25 June to 2 September and 22 June to 12 October for 1981 and 1982 , respectively. Stocking rates were .64 (moderate) and .98 (heavy) AUM's/ha for 1981 and 1982, respectively.

Five range sites, thin claypan, shallow, sandy, silty, and clayey, comprised 50, 32, 3,8 and 7\%, respectively, of the SDG treatment. Production and disappearance of current year's forage was estimated seasonally by clipping 20 paired, caged and uncaged, 0.25 $\mathrm{m}^{2}$ quadrats on each range site. Caged and uncaged quadrats were clipped each 40 days following the completed rotation of the cattle herd through paddocks. Grass, forb, and total herbaceous production for each year was determined by multiplying the percentage of each range site by the averaged grass, forb, and total herbaceous production estimated for that site and summing across sites. Forage disappearance was estimated as the difference in dry weight between paired, caged and uncaged quadrats and averaged by year as described for forage production determinations.

Four to 6 esophageally fistulated cows were utilized to collect diet samples from 3 adjacent paddocks. Cows were fasted overnight, then consecutive $1 \mathrm{hr}$ diet collections were made at dawn. Diet samples were collected prior to each of these paddocks being grazed by the cattle herd and immediately following the 5-day occupation of these same paddocks. Collections were made at 
approximately 40-day intervals corresponding with seasons and the rotation cycle. Seasons were designated early summer, summer, early fall, and fall and corresponded to late-June through midJuly, mid-July through mid-August, mid-August through midSeptember, and mid-September through early-October collection periods, respectively.

Dietary samples from each cow and collection were thoroughly mixed and subsamples removed and frozen. Samples were then lyophilized and nutrition samples ground to pass a 1 -mm screen.

Nutrient analyses included crude protein (CP) determined by the micro-Kjeldahl method (AOAC 1970), and in vitro digestible organic matter (IVDOM) determined by the procedures described by Tilley and Terry (1963) and Van Soest and Wine (1967).

Botanical composition of diets followed the microscopic analysis technique described by Kothmann (1968). Plant fragments were identified within 20 randomly selected microplots. Data were recorded by class and species of ingested plant.

Data from diets were analyzed as a split-plot design with year as the main plot and daily or seasonal collection periods as subplot treatments. Duncan's multiple range test was used to compare differences among means following analysis of variance (Steel and Torrie 1960).

\section{Results and Discussion}

In 1981, precipitation at the Dickinson Experiment Station Ranch Headquarters was $55 \%$ of the long-time average $(39 \mathrm{~cm})$. Resultant graminoid, forb, and total herbaceous production averaged 615,144 , and $759 \mathrm{~kg} / \mathrm{ha}$, respectively. This led to a shortened grazing season of $2 \frac{1}{2}$ months. Herbaceous disappearance was $55 \%$. Greater-than-average precipitation was received in $1982(66 \mathrm{~cm})$ resulting in estimated production of 725,483 , and $1,208 \mathrm{~kg} /$ ha of grass, forb, and total herbaceous production, respectively. The grazing season was terminated after 4 months with herbaceous disappearance estimated to be $41 \%$.

Seasonal percentages of CP and IVDOM differed in diets selected between the 2 years of the study (Table 1). With one exception: \% CP and IVDOM were less within each similar season of 1981 when compared to 1982 . Since the first year of the study was conducted under severe drought conditions, less forage, especially green, growing forage was available for cattle to graze. Consequently, cattle were forced to select more mature forage which probably contributed to the decreased nutrient percentages found in 1981 diets. In addition, herbaceous utilization was greater in 1981. A decrease in herbage allowance has been reported to reduce diet quality (Allison and Kothman 1979, Taylor et al. 1980).
Early summer and summer CP content of diets in 1981 were significantly greater than those selected in early fall (Table 1). Percentage CP in diets did not meet lactating cow requirements (9.2\%) (NRC 1984) in summer and early fall although dry, pregnant cow requirements $(5.9 \%)$ were met throughout the grazing season. Early summer dietary IVDOM in 1981 was significantly greater than that determined for summer or early fall. Only early summer diets exceeded 50\% IVDOM.

During 1982, \% CP and IVDOM content of diets selected by cows decreased from early summer through fall (Table 1). Mean $\%$ CP was significantly less in early fall and fall diets when compared to early summer diets. Summer \% CP content in cattle diets was also significantly greater than fall dietary CP. Beginning in early summer, \% IVDOM in forage selected by cows decreased significantly with each succeeding season. Early summer and summer dietary CP exceeded lactating cow requirements, while all seasonal diets selected in 1982 exceeded dry, pregnant cow requirements for CP. Diets selected throughout the 1982 grazing season exceeded 50\% IVDOM.

Few differences were found in the nutritive content of cattle diets collected at the beginning and end of a 5-day occupation period of selected research paddocks (Table 1). Over the 1981 grazing period, no differences in any season were determined for either dietary CP or IVDOM between the initiation and termination of grazing on paddocks. Two differences were noted in 1982. Early summer \% IVDOM and fall \% CP were greater in diets selected on the first day when compared to the last day of paddock occupation. The difference found for early summer \% IVDOM is probably of litle biological importance since values at this season were high. However, the difference determined for CP between first and last day diet collections on grazed paddocks in fall may be critical in cattle herd maintenance. Decreased dietary quality under intensive rotational grazing during some portion of the grazing period is in agreement with results reported by Heady (1961), Barnes (1977), and Sharrow (1983). Under the conditions of this study, a shortening of occupation periods or allowing access to a greater number of paddocks after forage maturation may help maintain dietary quality through improved selectivity at or near the level required by grazing livestock.

Over both years of the study, grass dominated cattle diets in all seasons (Table 2). However, several differences in diet selectivity were noted between years. In 1981, a drought year, a higher percentage of grass was found in cattle diets during the early summer and summer following movement into a fresh paddock than in 1982. In addition, the browse component of before grazed diets in fall 1981

Table 1. Crude protein $(\%)$ and in vitro digestible organic matter (\%) content of cattle diets selected over a 5-day occupation of paddocks under a short duration grazing system at the Dickinson Experiment Station Ranch Headquarters.

\begin{tabular}{|c|c|c|c|c|c|}
\hline \multirow[b]{2}{*}{ Ycar } & \multirow{2}{*}{$\begin{array}{l}\text { Collection } \\
\text { period }\end{array}$} & \multicolumn{4}{|c|}{ Season } \\
\hline & & Early summer & Summer & Early fall & Fall \\
\hline 1981 & $\begin{array}{l}\text { before } \\
\text { after } \\
\text { average } \\
\text { before } \\
\text { after } \\
\text { average }\end{array}$ & $\begin{array}{l}9.4 \pm .21^{1} \mathrm{bc}^{2} \\
8.7 \pm .21 \mathrm{~cd} \\
9.1 \pm .16 \mathrm{c} \\
11.5 \pm .79 \mathrm{a} \\
10.6 \pm .44 \mathrm{ab} \\
11.1 \pm .47 \mathrm{ab}\end{array}$ & $\begin{array}{c}8.5 \pm .19 \mathrm{~d} \\
8.5 \pm .25 \mathrm{~d} \\
8.5 \pm .15 \mathrm{~d} \\
10.0 \pm .57 \mathrm{bc} \\
8.9 \pm .52 \mathrm{~cd} \\
9.5 \pm .40 \mathrm{c}\end{array}$ & $\begin{array}{l}\text { protein } \\
6.9 \pm .23 \mathrm{e} \\
- \\
6.9 \pm .23 \mathrm{e} \\
8.2 \pm .28 \mathrm{de} \\
7.6 \pm .24 \mathrm{e} \\
8.0 \pm .20 \mathrm{de}\end{array}$ & $\begin{array}{l}- \\
- \\
6.9 \pm .13 \mathrm{e} \\
5.6 \pm .22 \mathrm{f} \\
6.3 \pm .20 \mathrm{ef}\end{array}$ \\
\hline $\begin{array}{l}1981 \\
1982\end{array}$ & $\begin{array}{l}\text { before } \\
\text { after } \\
\text { average } \\
\text { before } \\
\text { after } \\
\text { average }\end{array}$ & $\begin{array}{l}60 \pm .99 \mathrm{~cd} \\
59 \pm .71 \mathrm{~d} \\
60 \pm .61 \mathrm{~cd} \\
72 \pm 1.78 \mathrm{a} \\
65 \pm 1.53 \mathrm{bc} \\
69 \pm 1.32 \mathrm{ab}\end{array}$ & $\begin{array}{l}47 \pm .86 \mathrm{f} \\
45 \pm .73 \mathrm{f} \\
46 \pm .58 \mathrm{f} \\
63 \pm 1.16 \mathrm{~cd} \\
61 \pm .75 \mathrm{de} \\
62 \pm .75 \mathrm{cde}\end{array}$ & $\begin{array}{l}\text { le organic m } \\
43 \pm 1.16 \mathrm{f} \\
- \\
43 \pm 1.16 \mathrm{f} \\
59 \pm .94 \mathrm{e} \\
59 \pm .64 \mathrm{e} \\
59 \pm .59 \mathrm{e}\end{array}$ & $\begin{array}{l}- \\
- \\
52 \pm .71 \mathrm{f} \\
51 \pm 1.0 \mathrm{f} \\
52 \pm .62 \mathrm{f}\end{array}$ \\
\hline
\end{tabular}

IStandard error.

2Means within nutrients followed by a different letter differ at the 0.05 level.

${ }^{3}$ Averages are over 5 -day collection periods within seasons. 
Table 2. Botanical composition (\%) of cattle diets selected over 5-day occupations of paddocks under a short duration grazing system at the Dickinson Experiment Station Ranch Headquarters.

\begin{tabular}{|c|c|c|c|c|c|c|c|c|}
\hline \multirow[b]{2}{*}{$\begin{array}{l}\text { Forage class } \\
\text { and species }\end{array}$} & \multicolumn{4}{|c|}{ Before Grazing } & \multicolumn{4}{|c|}{ After Grazing } \\
\hline & $\begin{array}{l}\text { Early } \\
\text { summer }\end{array}$ & Summer & $\begin{array}{l}\text { Early } \\
\text { fall }\end{array}$ & Fall & $\begin{array}{l}\text { Early } \\
\text { summer }\end{array}$ & Summer & $\begin{array}{l}\text { Early } \\
\text { fall }\end{array}$ & Fall \\
\hline & \multicolumn{8}{|c|}{1981} \\
\hline Grass & $91 \pm 1.131 \mathrm{ab}^{2}$ & $94 \pm 1.99 \mathrm{a}$ & $85 \pm 3.14 b c$ & - & $83 \pm 1.10 c$ & $90 \pm 1.63 \mathrm{ab}$ & - & - \\
\hline Agropyron smithii & 32 & 31 & 23 & - & 32 & 25 & - & - \\
\hline Stipa comata & 14 & 7 & 1 & - & 13 & 7 & - & - \\
\hline Total cool-season & 64 & 43 & 24 & - & 58 & 38 & - & - \\
\hline Bouteloua gracilis & 21 & 43 & 56 & - & 21 & 44 & - & - \\
\hline Total warm-season & 27 & 51 & 61 & - & 25 & 52 & - & - \\
\hline Forb & $6 \pm .69 \mathrm{ef}$ & $2 \pm .54 \mathrm{e}$ & $1 \pm .45 \mathrm{e}$ & - & $16 \pm 1.14 \mathrm{hi}$ & $5 \pm .73 e$ & - & - \\
\hline \multirow[t]{2}{*}{ Browse } & $3 \pm .77 \mathrm{kl}$ & $4 \pm 1.51 \mathrm{k}]$ & $14 \pm 2.69 \mathrm{~m}$ & - & $1 \pm .21 \mathrm{k}$ & $5 \pm 2.311$ & - & - \\
\hline & \multicolumn{8}{|c|}{1982} \\
\hline Grass & $72 \pm 2.68 \mathrm{~d}$ & $82 \pm 2.13 \mathrm{c}$ & $87 \pm 1.41 b c$ & $87 \pm 1.65 b c$ & $75 \pm 2.04 d$ & $85 \pm 3.14 b c$ & $84 \pm .8 \mathrm{lbc}$ & $89 \pm 1.22 \mathrm{ab}$ \\
\hline Agropyron smithii & 48 & 44 & 10 & 11 & 44 & 34 & 11 & 13 \\
\hline Stipa comata & 2 & 7 & 3 & 3 & 4 & 8 & 4 & 2 \\
\hline Total cool-season & 60 & 61 & 29 & 29 & 58 & 54 & 25 & 25 \\
\hline Bouteloua gracilis & 9 & 16 & 49 & 47 & 13 & 23 & 47 & 52 \\
\hline Total warm-season & & 21 & 58 & 58 & 17 & 31 & 59 & 64 \\
\hline Forb & $24 \pm 3.19 \mathrm{j}$ & $14 \pm 2.41 \mathrm{gh}$ & $9 \pm .79 \mathrm{fg}$ & $9 \pm .85 f g$ & $20 \pm 1.58 \mathrm{ij}$ & $14 \pm 2.69 \mathrm{gh}$ & $10 \pm .93 \mathrm{fg}$ & $5 \pm .55 \mathrm{ef}$ \\
\hline Browse & $4 \pm 1.46 \mathrm{kl}$ & $4 \pm .51 \mathrm{kl}$ & $4 \pm 1.03 \mathrm{kl}$ & $4 \pm .87 \mathrm{kl}$ & $5 \pm 1.081$ & $1 \pm .45 \mathrm{k}$ & $6 \pm 1.301$ & $6 \pm 1.671$ \\
\hline
\end{tabular}

IStandard error.

2Means of plant classes followed by a different letter differ at the 0.05 level.

was greater than that determined for the comparable season in 1982. Conversely, forb availability and selection by cattle prior to paddocks being grazed was greater in all seasons of 1982 , a wet year, when compared to 1981 .

Seasonal diets in 1981 ranged from 85 to $94 \%$ grasses (Table 2). Selection of grass by cattle was significantly greater in summer when compared to the early fall grazing period. Western wheatgrass (Agropyron smithii Rydb.), needle-and-thread (Stipa comata Trin. \& Rupr.), total cool-season grasses, and forbs decreased in diets from early summer through early fall. Blue grama (Bouteloua gracilis H.B.K. Lag. ex. Steud.) and total warm-season grasses increased in diets as the grazing season progressed. Browse significantly increased in early fall cattle diets when compared to early summer and summer diets. The significant decrease in grass and increase in browse in 1981 cattle diets as the grazing season progressed is probably in response to the drought conditions since the limited amounts of grass available during the latter part of the grazing season were well cured while the previously unutilized browse component provided an alternative forage source of high nutrient quality. Shifts in cattle diets towards browse in fall have also been reported by Roath and Krueger (1982) and Kirby and Stuth (1982b).

In 1982, grasses again dominated the composition of seasonal cattle diets ranging from 72 to $87 \%$ of the diet (Table 2). Selection for grass was significantly less in early summer when compared to the latter seasons. Again western wheatgrass, needle-and-thread, and cool-season grasses decreased while blue grama and total warm-season grasses increased in diets as the grazing season advanced. Selection for forbs was significantly greater in early summer when compared to the following seasons. Browse was selected in low amounts throughout 1982.

Selection among forage classes varied with time spent in paddocks both years of the study (Table 2). During 1981, grass selection by cattle decreased over the 5-day occupation of paddocks in early summer, while forb selection increased during the same period. Browse selection showed no trend for the droughtshortened 1981 grazing season.

Diet selection of plant classes with seasons and occupation periods was more constant in 1982 than 1981 (Table 2). No differences in seasonal grass selectivity over the 5-day cattle occupation of paddocks were determined in 1982. Selection of grass during occupations varied only 2 to 3 percentage points in each of the seasonal collection periods. In addition, no differences were detected for forb or browse composition in diets between the initiation and termination of grazing on paddocks in 1982.

\section{Summary and Conclusions}

Extremes in precipitation received during the study led to a variation in plant classes and species available as forage. Grasses and forbs had a more limited availability and greater utilization in 1981 when compared to 1982 . Consequently, nutritional and botanical compositions of forage selected by cattle varied significantly between years and seasons.

Crude protein content of diets did not meet lactating cow requirements in early fall or fall either year of the study. However, CP did meet dry, pregnant cow requirements throughout seasonal diet collections both years of the study. A decline in dietary CP with advanced maturity and reduced availability of forage is in agreement with many grazing studies (Streeter et al. 1968, Obioha et al. 1970, Scales et al. 1974, Allison and Kothmann 1979, Kirby and Stuth 1982a, Yates and Wallace 1982). Earlier weaning of calves and / or supplementation of cows or calves in fall should help mitigate this nutritional deficiency in late season forage on seasonally grazed ranges.

Diets selected at the initiation and termination of grazing on paddocks generally decreased in CP and IVDOM. In late fall 1982, a significant decrease in dietary $\mathrm{CP}$ below the requirement needed for dry, pregnant cow was determined between the beginning and final day of paddock occupation. This may be critical in cow herd maintenance prior to winter. Despite not being statistically significant, the general decrease in diet quality during a paddock occupation might be of biological significance. A rapidly fluctuating and decreasing nutrient and forage supply should lead to less than optimum dietary selectivity, hence livestock productivity. Possibly a shortening of the occupation period after forage maturation or access to multiple paddocks may maintain dietary quality at or above levels required by grazing cattle without further managerial inputs. A reduction in stocking rate, supplementation, early calf weaning, etc., however, may be necessary to maintain or improve livestock performance after forage maturation. 
Botanically, grasses dominated the composition of diets both years of the study. Major grasses selected were western wheatgrass and blue grama with needle-and-thead less consistently selected. Despite some selection of forbs and browse, these plant classes were not observed as being consistently utilized under our short duration grazing system. This suggests that an alternate class of livestock may also need to be stocked in this region regardless of management system to make efficient use of these classes of forage.

\section{Literature Cited}

Allison, C.D., and M.M. Kothmann. 1979. Effect of level of stocking pressure on forage intake and diet quality of range cattle. Amer. Soc. Anim. Sci., West. Sec., Proc. 30:174-178.

A.O.A.C. 1970. Official methods of analysis. (11th ed.) Ass. of Off. Agr. Chem., Washington, D.C.

Barnes, D.L. 1977. An analysis of rotational grazing on veld. Rhodesia Agr. J. 74:147-151.

Heady, H.F. 1961. Continuous vs. specialized grazing systems: A review and application to the California annual type. J. Range Manage. 14:182-193.

Heitschmidt, R.K., R.A. Gordon, and J.S. Bluntzer. 1982a. Short duration grazing at the Texas Experimental Ranch: Effects on forage quality. J. Range Manage. 35:372-374.

Heitschmidt, R.K., J.R. Frasure, D.L. Price, and L.R. Rittenhouse. 1982 b. Short duration grazing at the Texas Experimental Ranch: Weight gains of growing heifers. J. Range Manage. 35:375-379.

Kirby, D.R., and J.W. Stuth. 1982a. Brush management influences the nutritive content of cattle diets in east-central Texas. J. Range Manage. 35:431-434.

Kirby, D.R., and J.W. Stuth. 1982b. Botanical composition of cattle diets grazing brush managed pastures in east-central Texas. J. Range Manage. 35:434-436.

Kothmann, M.M. 1968. The botanical composition and nutrient content of the diet of sheep grazing poor condition pasture compared to good condition pasture. Ph.D. Diss. Texas A\&M Univ., College Station, Texas.

Kothmann, M.M. 1980. Consideration of livestock needs in designing grazing systems for rangelands, p. 78-90. In:D.C. Church (ed.), Digestive Physiology and Nutrition of Ruminants; Vol. 3. Practical Nutrition. O\& M Books. Corvallis, Ore.
Launchbaugh, John L., Clenton E. Owensby, Frank L. Schwartz, and Larry R. Corah. 1978. Grazing management to meet nutritional and functional needs of livestock, p. 541-546. In: D.N. Hyder (ed.), Proc. 1st Internat. Range Cong., Soc. Range Manage. Pub. Denver, Colo.

Lewis, James K. 1969. Range management viewed in an ecosystem framework, p. 97-187. In: G.M. Van Dyne (ed.) The Ecosystem Concept In Natural Resource Management, Academic Press. New York.

N.R.C. 1984. Nutrient requirements of domestic animals; No. 6. Nutrient requirements of beef cattle. Nat. Acad. Sci. Washington, D.C.

Obioha, F.C., D.C. Clanton, L.R. Rittenhouse, and C.L. Streeter. 1970. Sources of variation in chemical composition of forage ingested by esophageal fistulated cattle. J. Range Manage. 23:133-135.

Roath, L.R., and W.C. Krueger. 1982. Cattle grazing influence on a mountain riparian zone. J. Range Manage. 35:100-103.

Savory, A. 1978. A holistic approach to ranch management using short duration grazing, p. 555-557. In: D.N. Hyder (ed.), Proc. 1st Internat. Range. Cong., Soc. Range Manage. Pub. Denver, Colo.

Scales, G.H., A.H. Denham, C.L. Streeter, and G.M. Ward. 1974. Winter supplementation of beef calves on Sandhill range. J. Anim. Sci. 38:442-448.

Sharrow, S.H. 1983. Forage standing crop and animal diets under rotational vs. continuous grazing. J. Range Manage. 36:447-450.

Steel, R.D.G., and J.H. Torrie. 1960. Principles and procedures of statistics. McGraw-Hill, Inc. New York.

Streeter, C.L., D.C. Clanton, and O.E. Hoehne. 1968. Influence of advance in season on nutritive value of forage consumed by cattle grazing western Nebraska native range. Nebraska Agr. Exp. Sta. Bull. 227.

Taylor, Charles A., M.M. Kothmann, L.B. Merrill, and Doak Elledge. 1980. Diet selection by cattle under high-intensity low-frequency, short duration, and Merrill grazing systems. J. Range Manage. 33:428-434.

Tilley, J.M.A., and R.A. Terry. 1963. A two-stage technique for the in vitro digestion of forage crops. J. Brit. Grassld. Soc. 18:104-111.

U.S.D.A., S.C.S. 1982. Soil Survey of Dunn County, North Dakota.

Van Soest, P.J., and R.H. Wine. 1967. Use of detergents in the analysis of fibrous feeds. IV. Determinations of plant cell-wall constituents. J. Ass. Off. Agr. Chem. 50:50-55.

Whitman, W.C., and M.K. Wali. 1975. Prairie: A multiple view. Univ. N.D. Press, Grand Forks.

Yates, D.A., and J.D. Wallace. 1978. Cattle diets on irrigated pasture. J. Range Manage. 31:213-215.

\section{Advertising Information \\ Journal of Range Management Rangelands}

Deadline Dates for Advertising

\begin{tabular}{ll}
\multicolumn{2}{c}{ Journal of Range Management } \\
January Issue & - December 4,1986 \\
March Issue & - February 5, 1987 \\
May Issue & - April 6, 1987 \\
July Issue & - June 8, 1987 \\
September Issue & - August 10, 1987 \\
November Issue & - October 8, 1987
\end{tabular}

\begin{tabular}{ll}
\multicolumn{2}{c}{ Rangelands } \\
February Issue & - December 18, 1986 \\
April Issue & - March 10, 1987 \\
June Issue & - May 7, 1987 \\
August Issue & - July 8, 1987 \\
October Issue & - September 8, 1986 \\
December Issue & - November 4, 1987
\end{tabular}

Copy must arrive by the above dates. For 1-time advertising that requires cover space or an entire page, an insertion order must arrive two (2) weeks prior to the above dates.

Art copy requiring color separations not furnished by the advertiser should arrive one (1) week prior to the above dates.

Full Pages Available in 1987

Journal of Range Management

Covers 2 and 3 (color \& black \& white)

Pages 2-96 (black \& white)

\section{Rangelands}

Covers $3 \& 4$ (color \& black \& white)

Pages 3 - 48 (black \& white) 